\title{
Global and Local Sources of Risk in Eastern European Emerging Stock Markets
}

\author{
Elena FEDOROVA - Lappeenranta University of Technology (LUT), School of Business \\ (elena.fedorova@lut.fi) \\ Mika VAIHEKOSKI - Turku School of Economics (TSE) and Lappeenranta University \\ of Technology (LUT) (mika.vaihekoski@tse.fi)
}

\begin{abstract}
We study a pricing model for global and local sources of risk in six Eastern European emerging stock markets. Utilizing GMM estimation and an unconditional asset-pricing framework with and without time-varying betas, we perform estimations based on monthly data from 1996 to 2007 for Poland, the Czech Republic, Hungary, Bulgaria, Slovenia, and Russia. Most of these markets display considerable segmentation; the aggregate emerging market risk, as opposed to global market risk, is the significant driver for their stock market returns. It also appears that currency risk is priced into stock prices. The difference between local and global interest rates can be used to model the time-variation in the betas for both sources of risk.
\end{abstract}

\section{Introduction}

International investors and researchers have been drawn to emerging markets because of their rapid economic development, high returns, and potential for diversification as well as because of the series of reforms on these capital markets. The big challenges for researchers, in turn, have been devising ways to price risk and distinguish the roles of global and local sources of risk in these markets. Several empirical studies find market segmentation is typically larger in emerging markets than in developed markets, suggesting that local sources of risk are more critical than international sources (e.g. Korajczyk, 1995; Shackman, 2005). On the other hand, Bekaert and Harvey (1995), who test a two-factor asset-pricing model in which the conditional expected returns of a country are affected by global and local sources of risk, see evidence of a rising role for global sources of risk and a diminishing role for local risk sources.

The more recent literature is mixed on the subject of financial integration. Tai (2006) and de Jong and de Roon (2005) claim markets become more integrated after equity market liberalization. Brooks and Del Negro (2002), on the other hand, note that Europe has become more integrated while elsewhere segmentation has lately increased. Some researchers see no evidence of increased integration over time (e.g. King and Segal, 2008).

Most papers on currency risk in emerging markets conclude that it is priced on stock markets (e.g. De Santis and Imrohoroglu, 1997; Tai, 2006; Saleem and Vaihe-

\footnotetext{
* The authors are grateful to the anonymous referees for their comments, which greatly improved the paper. They would also like to thank Niklas Ahlgren, Iikka Korhonen and Timo Rothovius and other participants at the GSF Winter Workshop and at the Bank of Finland Research Seminar for their helpful comments and insights.
} 
koski, 2008). However, the role of currency risk is still somewhat controversial. Several papers assume that investors can hedge country-specific currency risk and that multilateral currency risk is the sole form of currency risk that matters. Other papers have found support for the pricing of bilateral currency risk (see e.g. Antell and Vaihekoski, 2007).

Here, we study the role of global and local sources of risk in six Eastern European stock markets: Russia, Poland, Hungary, the Czech Republic, Bulgaria, and Slovenia. We test for whether aggregate emerging market risk in the sample countries is priced together with currency risk (bilateral or multilateral). In addition, we test a conditional version of the pricing model that allows the betas to vary over time linearly on one variable - the interest difference between local and global short-term interest rates. This variable is arguably key in measuring the local economic conditions and financial stability, and hence suitable for modeling risk sensitivity. Our sample period runs from 1996 to 2007. All sample countries displayed high growth during the observation period and offered local and foreign investors a wide range of investment opportunities.

The paper is organized as follows. The second section presents the theoretical background and the empirical formulation of the testable model. Section 3 introduces the sample countries and the data used in the study. Section 4 provides descriptive statistics for the data and presents the results from the analysis. Concluding remarks and suggestions for future research are stated in Section 5.

\section{Research Methodology}

\subsection{Theoretical Background}

Under full integration, expected returns on assets should be the same after adjusting for their risk characteristics. A stock market is considered legally integrated when the state and the exchange impose no restrictions on securities transactions of local or foreign investors seeking to diversify their investment portfolios in international capital markets. With financial market integration, we assume assets in all national markets have the same set of risk factors and accordingly the same risk premium for each factor (though not the same risk sensitivity).

Adler and Dumas (1983) contend that the global value-weighted market portfolio is the relevant risk factor. If investors do not hedge against exchange rate risks and a risk-free asset exists, the conditional version of the world capital asset-pricing model (CAPM) implies the following restriction for the nominal excess returns:

$$
E_{t}\left[r_{i, t+1}\right]=\beta_{i, t+1} E_{t}\left[r_{m, t+1}\right]
$$

where $E_{t}\left[r_{i, t+1}\right]$ and $E_{t}\left[r_{m, t+1}\right]$ are the conditional expected excess returns on asset $i$ and the global market portfolio at time $t$. All returns are measured in excess of the risk-free rate of return $r_{f t}$ for the period $t$ to $t+1$ in the numeraire currency. Currency risk is not priced, as investors diversify away from it as they do for the idiosyncratic risk of companies. Note that the model also holds for the local market portfolio since the local market portfolio is tradable.

While the basic world CAPM can be used to get the expected excess returns on an integrated stock market, real-world markets are not fully integrated into 
the world equity market. Errunza and Losq (1985), therefore, suggest we include a local risk factor for partially segmented markets. Hence, for any asset $i$, the excess return is given by the following model:

$$
E_{t}\left[r_{i, t+1}\right]=\beta_{i, t+1}^{g} E_{t}\left[r_{g m, t+1}\right]+\beta_{i, t+1}^{l} E_{t}\left[r_{l m, t+1}\right]
$$

where $g$ and $l$ refer to the global and local market portfolios and betas, respectively.

Moreover, any investment in a foreign asset is always a combination of investment in the performance of the asset itself and the movement of the foreign currency relative to the domestic currency. Adler and Dumas (1983) show that where purchasing power parity (PPP) does not hold, investors treat real returns differently and thus seek to hedge against exchange rate risks. ${ }^{1}$ Specifically, the risk induced by PPP deviations is measured as the exposure to inflation risk and the relevant currency risk. Assuming domestic inflation is non-stochastic over short periods of time, the PPP risk contains only the relative change in the exchange rate between the numeraire currency and the currency of $C+1$ countries (e.g. De Santis and Gérard, 1998). In this case, the conditional asset-pricing model for partially segmented markets implies the following restriction for the expected return of asset $i$ in the numeraire currency:

$$
E_{t}\left[r_{i, t+1}\right]=\beta_{i, t+1}^{g} E_{t}\left[r_{g m, t+1}\right]+\beta_{i, t+1}^{l} E_{t}\left[r_{l m, t+1}\right]+\sum_{c=1}^{C} \beta_{i, t+1}^{c} E_{t}\left[r_{c, t+1}\right]
$$

where $\beta_{c, t+1}$ is the conditional currency beta for currency $c$. Unfortunately, this model becomes intractable when $C$ is large. Thus, one must focus on a subset of currencies or use a more parsimonious measure for currency risk. Taking from Ferson and Harvey (1993) and Harvey (1995b) on the use of a single aggregate exchange risk factor to proxy for deviations from PPP, the model (3) boils down to a three-factor model.

\subsection{Empirical Formulation and Econometric Considerations}

We test our asset-pricing models with estimations obtained with the generalized method of moments (GMM). ${ }^{2}$ The GMM is efficient among the class of instrumental estimators defined by orthogonality conditions (Greene, 2008). The GMM method also has the advantage of not relying on the assumption of normally distributed asset returns; a disturbance term can be both serially dependent and conditionally heteroskedastic (MacKinlay and Richardson, 1991). This feature of GMM is particularly beneficial in studies using returns from emerging markets, as they have often been found to be non-normally distributed and show serial correlation (e.g. Harvey, 1995b).

\footnotetext{
${ }^{1}$ Currency risk may enter indirectly into asset pricing if companies are exposed to unhedged currency risk (e.g. through foreign trade or foreign debt). Empirical evidence has found conflicting support for the pricing of foreign exchange rate risk (e.g. Jorion 1990, 1991; Roll, 1992; De Santis and Gérard, 1997, 1998; and Doukas, Hall, and Lang, 1999).

${ }^{2}$ The GMM was first introduced by Hansen (1982) for the estimation and testing of a wide range of econometric models. It has since been used for a wide range of econometric applications. Currently, the GMM approach predominates in parameter estimation and hypothesis testing of time-varying parameter CAPM and latent variables models.
} 
The unconditional beta pricing relation here implies the following error terms for asset $i, u_{i t}=r_{i t}-\alpha_{i}-\boldsymbol{F}_{t} \boldsymbol{\beta}_{i}$, where $r_{i t}$ is the realized excess return, $\alpha_{i}$ is the pricing error (Jensen's alpha), $\boldsymbol{F}_{\boldsymbol{t}}$ is a $1 \times K$ vector of excess risk factor returns, and $\boldsymbol{\beta}_{i}$ is a $K \times 1$ vector of risk sensitivities (betas). Since all our risk factors are tradable, the asset-pricing model implies that pricing errors are zero when the model holds and the risk factors used are multifactor-efficient. The orthogonality conditions implied by the model are against the risk factor returns and the constant. The model is fully identified, as the number of orthogonality conditions and parameters are the same.

\section{Data}

We conduct our tests on six Eastern European countries over the sample period of January 1996 to December 2007. Although most Eastern European countries opened stock markets in the early 1990s, thinness of trading makes the initial data unreliable. High quality data series do not become available until mid-decade as the markets find their feet. Tests are conducted from a US investor's point of view, so all returns are measured in US dollars. We use monthly continuously compounded asset returns based on month-end observations of total return market indices. For calculating excess returns, we apply a one-month holding period return calculated from the one-month Eurodollar rate using the approach recommended in Vaihekoski (2007). All data are extracted from Thomson Datastream, with the exception of the US currency index, which is taken from the US Federal Reserve Economic Data (FRED) database.

\subsection{Sample Countries and Test Assets}

While all six sample countries (Russia, Poland, Hungary, the Czech Republic, Bulgaria, and Slovenia) ${ }^{3}$ have made the transition from communist to capitalist systems, their economic and political developments diverge in many respects. Five have joined the EU (Poland, Hungary, Czech Republic, and Slovenia in May 2004, and Bulgaria in January 2007), while Russia has never entertained the notion of EU membership. Slovenia adopted the euro in January 2007, while the other countries retain their own currencies.

While the sample countries had stock markets before WWI, their stock exchanges were closed during the communist era. Slovenia was the first to re-establish its exchange (Ljubljana Stock Exchange, 1989), followed by Hungary (Budapest Stock Exchange, 1990), Bulgaria (Bulgarian Stock Exchange-Sofia, 1991), and Poland (Warsaw Stock Exchange, 1991). The Russian stock market (Moscow Stock Exchange) opened in 1992 and the Prague Stock Exchange in the Czech Republic in 1993. At the outset, the Russian and Czech stock markets were clearly in a league of their own in terms of size compared to the other stock markets in the sample (see Table 1). During the sample period, the Russian stock market quickly emerged as the largest by far, even though all stock markets in the sample increased in size several fold.

\footnotetext{
${ }^{3}$ The countries were selected on the basis of availability of the MSCI or IFC total return stock market indices for the full sample period. These indices are typically available only few years after the opening of the stock market. As a result, three potential countries were excluded from this study: Slovakia (Bratislava Stock Exchange, established in 1991), Romania (Bucharest Stock Exchange, 1995), and Ukraine (PFTS Stock Exchange, 1997).
} 
Table 1 Sample Market Capitalizations, 1995 and 2005

End-of-period levels (USD million)

\begin{tabular}{lcr}
\hline Country & 1995 & 2005 \\
\hline Bulgaria & 61,0 & 5,086 \\
Czech Republic & 15,664 & 38,345 \\
Hungary & 2,399 & 32,576 \\
Poland & 4,564 & 93,873 \\
Russia & 15,863 & 548,579 \\
Slovenia & 1,235 & 7,899 \\
\hline
\end{tabular}

Sources: Emerging Market Factbook (1999) and Global Stock Markets Factbook (2006).

As test assets in the analysis, we utilize market portfolios from each sample country. As a proxy for the local market portfolios, we use the ever-popular MSCI and International Finance Corporation (IFC) indices. ${ }^{4}$ All indices strive to provide wide coverage, while excluding the most illiquid companies. They are also adjusted for stock splits and new issues, and include gross dividends (total pre-tax return for investors).

\subsection{Risk Factors}

We now test the pricing of three different sources of risk in our sample countries. Global market risk is proxied using the global equity market portfolio with returns calculated from the MSCI world equity total return index. This approach has frequently been used in earlier studies (e.g. Bekaert and Harvey, 1995; De Santis and Gérard, 1998; and Hunter, 2006).

Risk due to market segmentation is proxied using an aggregate emerging market portfolio. Returns are calculated from the aggregate Datastream emerging market total return index.

For exchange rate risk, we consider two proxies. The first is the broad, trade-weighted, US currency index - an aggregate, multilateral currency index that weights the average foreign exchange value of the US dollar against the currencies of 26 major US trading partners, including the euro area, Canada, Japan, and several major emerging markets. The trade-weighted US currency index has also been used in previous studies (e.g. Harvey, 1995a). Our second proxy is the bilateral country-specific exchange rate change against the US dollar. Returns are calculated as the reverse logarithmic difference in the index or exchange rates. ${ }^{5}$

Table 2 contains summary statistics for the monthly returns of the test assets and risk factors. Panel A in Table 2 contains the first four moments. The average returns and volatilities are annualized. The mean returns for the world and emerging stock equity markets are $8.3 \%$ and $14.1 \%$ annually. The risk-free rate is 4.2 on average over the sample period. Out of the sample countries, the Russian stock market provides US investors with the highest returns $26.9 \%$ per annum. The Bulgarian stock market performs the worst; its mean return is $-9.2 \%$ during the analyzed pe-

\footnotetext{
${ }^{4}$ We use mainly MSCI indices following earlier studies, but IFC indices are used in the case of Bulgaria and Slovenia as the MSCI indices do not cover the full sample period.

${ }^{5}$ Higher index values indicate US dollar appreciation. Thus, ceteris paribus, an investment in a foreign currency asset gives a negative return if the US dollar appreciates during the investment period.
} 


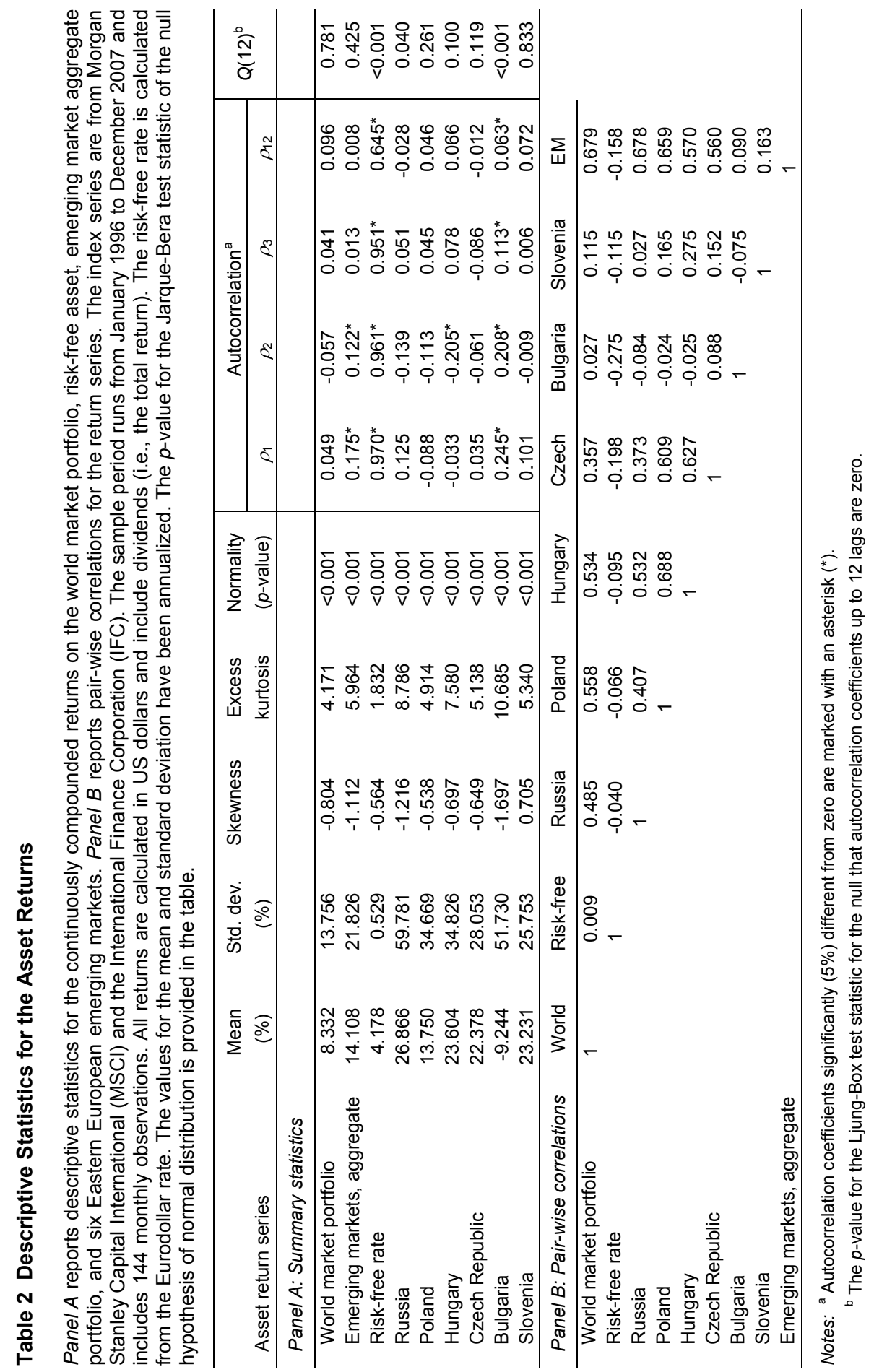




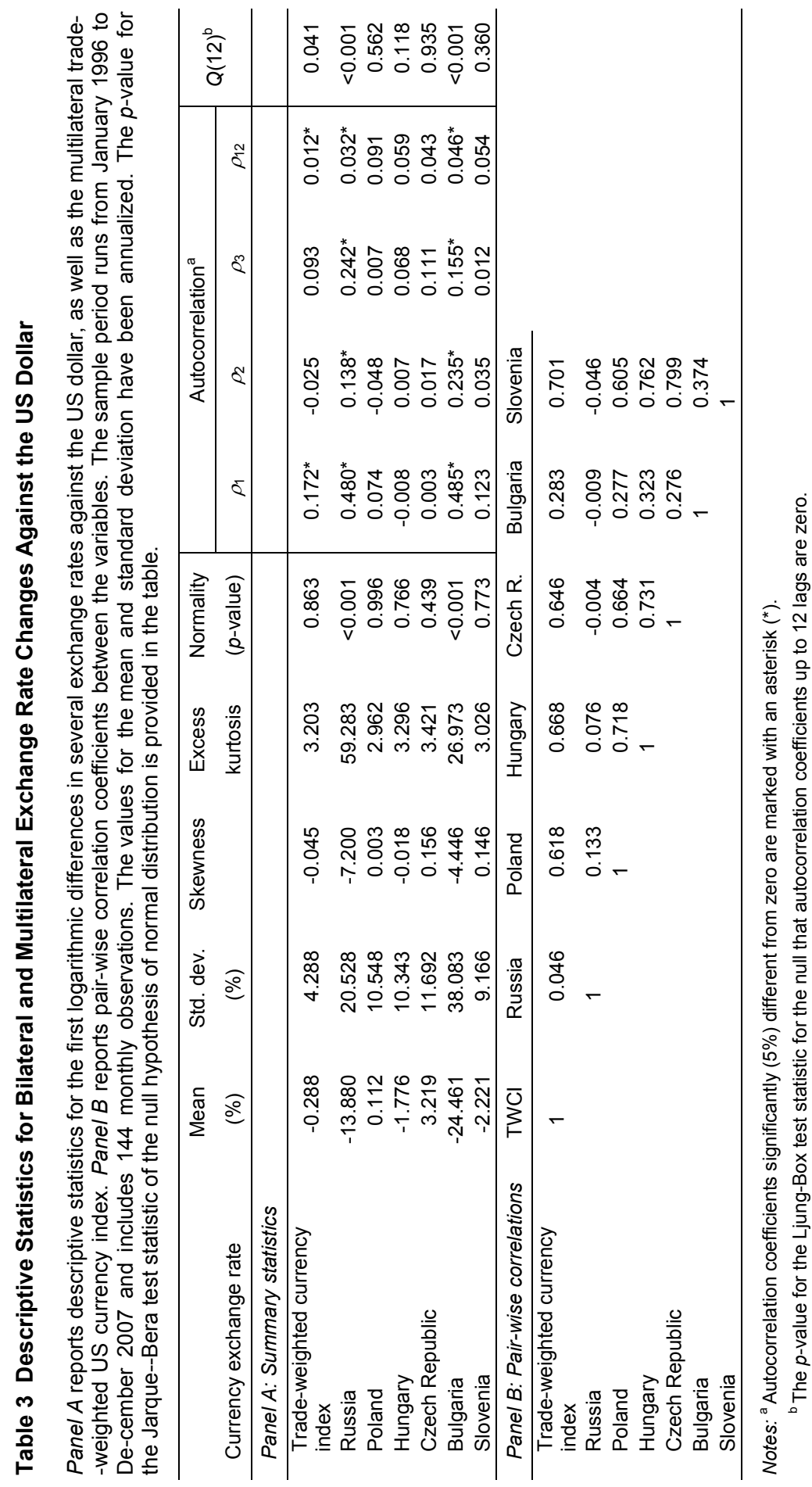




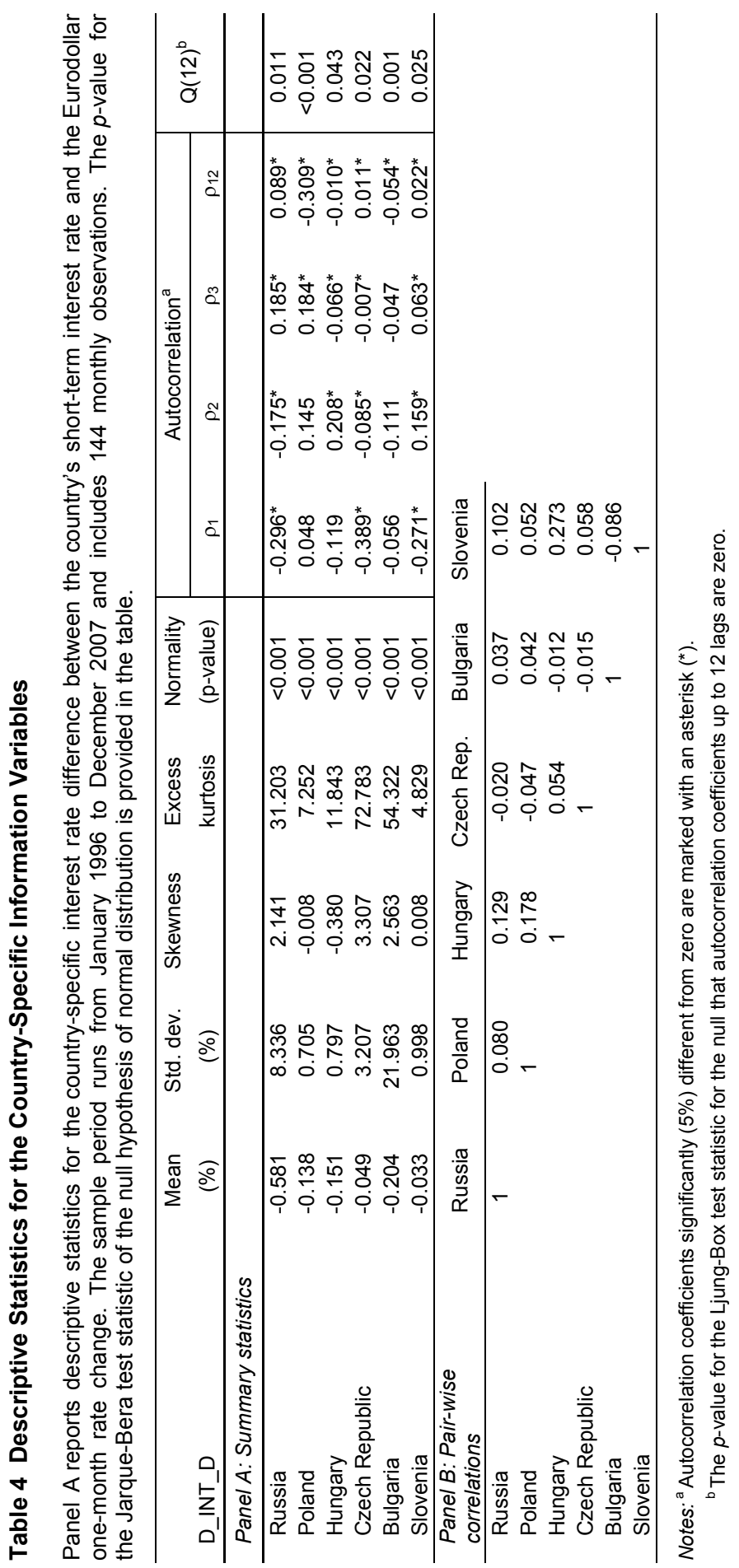

Finance a úvěr-Czech Journal of Economics and Finance, 59, 2009, no. 1 
riod. $^{6}$ As one would expect, the world portfolio and emerging market aggregate portfolio have the lowest standard deviations (13.76 and 21.83, respectively). All sample countries display surprisingly high volatility, with Russia having the highest standard deviation $(59.78 \%)$.

To check the null hypothesis of normal distribution, we use the Jarque-Bera test statistic ( $p$-values reported). All return series show evidence against normal distribution. In addition, we study the autocorrelation in the returns. We report the first three autocorrelation coefficients and Ljung-Box test statistic (12 lags) for each return series. Somewhat surprisingly, only Bulgaria shows evidence of first-order autocorrelation.

Panel B in Table 2 reports pair-wise correlations among asset returns. The emerging market aggregate index is highly correlated with the world one (0.679). The highest correlation between the sample countries is between the Hungarian and Polish stock markets (0.688). Bulgaria and Slovenia show fairly low values of correlation.

Table 3 reports descriptive statistics for changes in bilateral and multilateral exchange rates. The values for the means and standard deviations are again annualized to get the average depreciation (appreciation) rate for the currency. Panel A shows the US currency was surprisingly stable during the sample period (volatility of $4.288 \%$ per annum), depreciating only slightly overall (mean return $0.288 \%$ p.a.) against the currencies of major trade partners. In sub-period analysis, the dollar appreciates up to 2003 before the trend reverses. This is not the case for most of the sample countries. The Bulgarian lev lost the most value against the dollar during sample period (-24.46\% per annum, on average). The Russian ruble also sees an annualized depreciation of $-13.88 \%$. The Polish zloty and the Czech koruna, on average, appreciate slightly against of the dollar: $0.11 \%$ and $3.22 \%$, respectively. All the sample countries also show high volatility in their exchange rate changes with Bulgarian lev having the highest standard deviation (38.08\% per annum). There is also evidence of autocorrelation for most of the currencies.

Panel B in Table 3 reports pair-wise correlations among country bilateral and multilateral exchange rate changes. The Russian rouble exchange rates are not highly correlated with the exchange rates of the other countries in our analysis. The Bulgarian exchange rates correlate with most countries, but not as highly as the exchange rates of the other countries.

\subsection{Information Variables}

Following earlier studies, we use conditioning variables to model the time-variation in the betas. We choose local information variables to do this. Due to our short sample periods, we limit the number of parameters in the estimation and, as a result, we pick only one variable that potentially can show evidence of increases (or decreases) in a country's sensitivity to the selected sources of risk. The variable chosen here is the difference between the country's local interbank money market interest rate and the Eurodollar one-month rate change at the end of month $t-1$. Similar interest differentials are frequently used to describe the financial situation

\footnotetext{
${ }^{6}$ The negative return for investment on the Bulgarian stock market is mostly driven by the decreasing value of the Bulgarian currency against the US dollar. The change in the value of the Bulgarian currency in US dollars is $-24.40 \%$ on average per annum.
} 
and economic stability of a country. Moreover, the concept of interest rate parity relates the interest rates to the expected change in the value of currencies. This variable is easily observable, comparable across countries, and available to investors on a timely basis. Since the interest differentials show extremely high autocorrelation, we use the first difference of the differential in the following analysis.

Table 4 shows the descriptive statistics for the time series and pair-wise correlations. ${ }^{7}$ All countries show decreasing interest differential on average, which implies that the interest rates in the sample countries are approaching the international average. We take this as evidence of an improving local economic situation and increased financial integration. The biggest changes are observed for Russia $(-0.581 \%)$ and Bulgaria (-0.204\%). The lowest value is observed for the case of Slovenia $(-0.03 \%)$. The highest volatility is observed in the case of Bulgaria $(21.96 \%)$. The autocorrelation coefficients are significant for all countries and up to twelve lags. The highest correlation between local information variables is between Hungary and Slovenia (0.27) and Hungary and Poland (0.18).

\section{Empirical Results}

\subsection{Correlation Analysis}

We start our analysis by studying the time-series development of the correlation between the sample countries and world equity portfolio returns. Potentially, the analysis can provide evidence on the development of integration between the sample countries and global equity markets. Figure 1 gives the 12-month rolling-window correlation coefficients.

The overall observation from the figure is that the correlations increased during the sample period as one would expect. The correlation rises especially in the cases of Slovenia, the Czech Republic, and Bulgaria. The correlations for Russia, Hungary, and Poland first increase, then decrease, during the time period. This may express political instability and regulatory changes in equity markets in these countries. Exchange rate fluctuations may have also contributed to the changes in the correlation. The correlation between world equity portfolio returns and the returns of the aggregate emerging markets index varies slightly over the period of analysis. In the final year (2007), the correlation decreases based on the 12-month rolling correlation. Surprisingly, in the summer of 2007 the correlation of the emerging market aggregate index with the world equity index started to decrease rapidly, while the corresponding correlation of the sample country indices continues to show a tendency to increase.

\subsection{Main Results}

Our empirical tests of the asset-pricing models are based on GMM estimations. As a result of the descriptive analysis of the asset returns and the information variables, we apply the Newey-West (1987) autocorrelation and heteroskedasticity consistent covariance matrix estimator in our GMM estimation with lags set to one.

\footnotetext{
${ }^{7}$ The highest average interest rate differentials (not reported) between the local interbank money market rate and the Eurodollar one-month rate are observed for Russia $(15.80 \%)$ and Bulgaria $(15.05 \%)$, and the lowest for the Czech Republic (2.13\%) and Slovenia (2.38\%).
} 

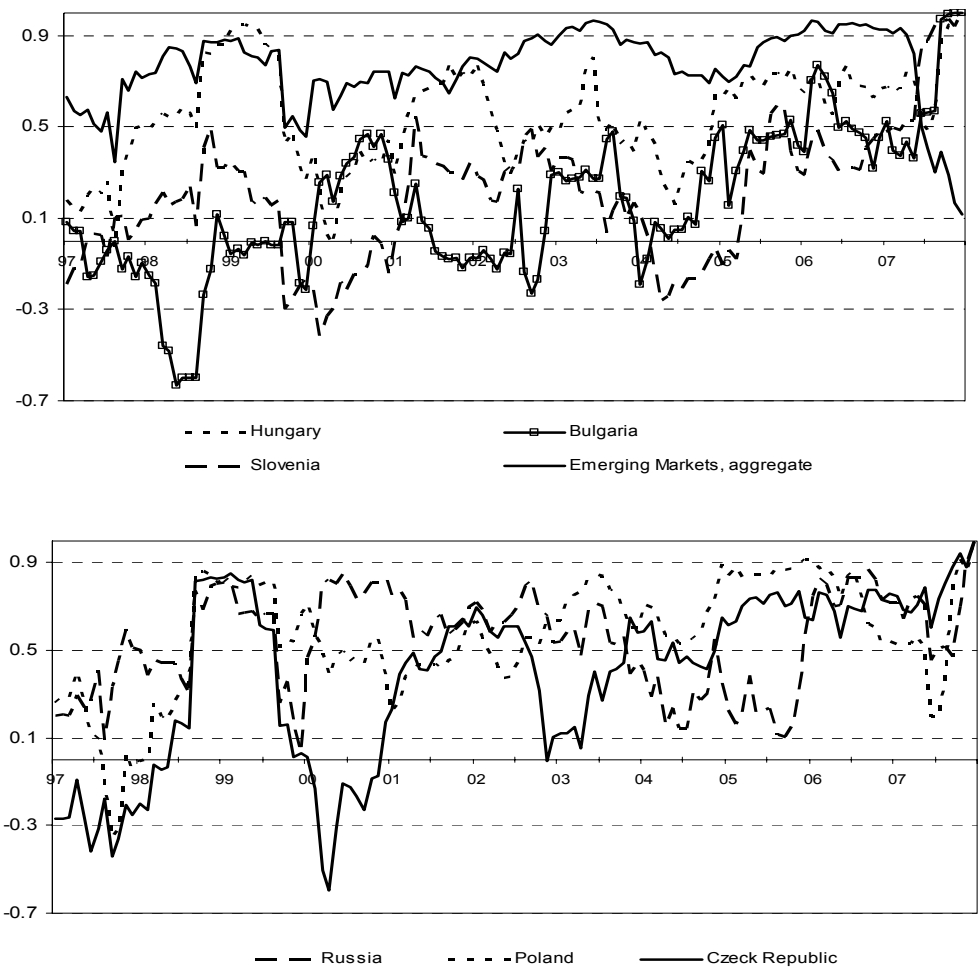

We let the system do only one iteration over the weighting matrix. ${ }^{8}$ The betas are initially assumed to be time invariant (i.e., constant in the estimation). The model is estimated jointly as a system for all test assets.

Our initial tests are based on the world CAPM, where the only source of risk is the global market, and on the partially segmented international CAPM, where the model is augmented with the aggregate emerging market risk. We test the model using six country portfolios. Tables 5 and 6 report the results from the GMM estimation.

Table 5 shows that the world market risk is found to be statistically significant for all countries except Bulgaria. Somewhat surprisingly, the average pricing errors do not differ statistically significantly from zero. The result is in line with the world CAPM, but the overall level of the pricing errors is still almost at par with the average excess returns, which suggests that the model is not able to fully explain the relationship between risk and return.

${ }^{8}$ This two-stage procedure is asymptotically efficient. It would also be possible to iterate the procedure until the parameter estimates and minimized objective function converge. However, the iterative process improves the finite-sample performance of the GMM most when the number of parameters is large (see Campbell et al., 1997). As a robustness check, we compared the results using both methods. They are basically similar. 


\section{Table 5 Results for the World CAPM}

The results from the tests on the unconditional world CAPM are reported below. Standard errors are reported below in alpha- and beta-parameter estimates. Significant parameters are marked with *, ${ }^{* *}$, and ${ }^{* * *}(10 \%, 5 \%$, and $1 \%$ levels of significance, respectively). The estimation is conducted using the GMM with the Newey-West (1987) autocorrelation and heteroskedasticity consistent covariance matrix with one iteration over the weighting matrix. The NW lags have been set to one. The model is fully identified. The Wald test is against the null hypothesis that the parameters in question are jointly zero for all assets (the $p$-value is provided in parenthesis). The sample period runs from January 1996 to December 2007 and includes 144 monthly observations. All returns are calculated from the month-end total return indices in US dollars and in excess of risk-free rate.

\begin{tabular}{|c|c|c|c|c|}
\hline & \multicolumn{2}{|c|}{ Average } & \multirow{2}{*}{$\begin{array}{c}\text { World market risk } \\
\text { Beta }(\beta)\end{array}$} & \multirow{2}{*}{$\begin{array}{c}\text { Adj. } R^{2} \\
\text { One-factor model }\end{array}$} \\
\hline & Excess return & Pricing error $(\alpha)$ & & \\
\hline \multirow{2}{*}{$\begin{array}{l}\text { Emerging } \\
\text { Markets }\end{array}$} & 0.008 & 0.004 & $1.087^{* * *}$ & 0.462 \\
\hline & & 0.004 & 0.127 & \\
\hline \multirow[t]{2}{*}{ Russia } & 0.019 & 0.012 & $2.117^{* * *}$ & 0.237 \\
\hline & & 0.014 & 0.484 & \\
\hline \multirow[t]{2}{*}{ Poland } & 0.008 & 0.003 & $1.413^{* * *}$ & 0.313 \\
\hline & & 0.007 & 0.221 & \\
\hline \multirow[t]{2}{*}{ Hungary } & 0.017 & 0.011 & $1.366^{* * *}$ & 0.283 \\
\hline & & 0.007 & 0.258 & \\
\hline \multirow[t]{2}{*}{ Czech Republic } & 0.015 & $0.013^{*}$ & $0.742^{* * *}$ & 0.125 \\
\hline & & 0.007 & 0.233 & \\
\hline \multirow[t]{2}{*}{ Bulgaria } & -0.011 & -0.012 & 0.142 & -0.006 \\
\hline & & 0.014 & 0.220 & \\
\hline \multirow[t]{2}{*}{ Slovenia } & 0.016 & $0.015^{\star *}$ & $0.222^{*}$ & 0.007 \\
\hline & & 0.007 & 0.126 & \\
\hline Wald-test & & 10.909 & $138.587^{\star \star * *}$ & Aver. Adj. $R^{2}$ \\
\hline ( $p$-value) & & $(0.143)$ & $(<0.001)$ & 0.202 \\
\hline
\end{tabular}

The situation changes somewhat when we add the emerging market risk factor (note that there is one test asset less in Table 6). The overall level of the pricing errors is lower, even though the alpha parameter is marginally significant ( $p$-value $9.7 \%$ ). The emerging markets risk is highly significant for most of the countries and the world market risk is no longer significant. In addition, including emerging market risk in the pricing model increases the overall explanatory power of the model $(6.1 \%$ on average). Wald tests on the individual parameters across assets support the hypothesis that both the world market risk and emerging market risk factors have explanatory power over the excess returns for emerging markets in our analysis. ${ }^{9}$

Our next model adds currency risk into the model. Initially, we use two competing proxies for the currency risk. The first is an aggregate, multilateral currency index; the second is country-specific bilateral currency exchange rates. The results

\footnotetext{
${ }^{9}$ The Wald-test statistic is calculated as follows: $W=(\boldsymbol{R} \boldsymbol{b}-\boldsymbol{r}){ }^{\prime}(\boldsymbol{R C R})^{-1}(\boldsymbol{R} \boldsymbol{b}-\boldsymbol{r}) \sim \chi^{2}$ with $J$ degrees of freedom, where $\boldsymbol{R}$ and $\boldsymbol{r}$ are $(J \times M)$ and $(J \times 1)$ matrices of restrictions, $\boldsymbol{b}$ is the $(M \times 1)$ vector of the estimated coefficients, $\boldsymbol{C}$ is the estimated Newey-West covariance $(M \times M)$ matrix, $J$ is the number of portfolios, and $M$ is the number of equations times the number of parameters estimated in each equation. In the tests, $\boldsymbol{R}$ is a matrix of zeros, except for those coefficients that are currently tested, and $\boldsymbol{r}$ is a vector of zeros.
} 


\section{Table 6 Results for the Two-Factor APM}

The results reported here are for the unconditional two-factor international asset-pricing model. The first risk factor is the world market portfolio. The second is aggregated emerging market portfolio. Standard errors are reported below in the alpha- and beta-parameter estimates. Significant parameters are marked with ${ }^{*},{ }^{* *}$, and ${ }^{* * *}(10 \%, 5 \%$, and $1 \%$ levels of significance, respectively). The estimation is conducted using the GMM with the Newey-West (1987) autocorrelation and heteroskedasticity consistent covariance matrix with one iteration over the weighting matrix. The NW lags have been set to one. The model is fully identified. The Wald test is against the null hypothesis that the parameters in question are jointly zero (the $p$-value is provided in parenthesis). All returns are calculated from the month-end total return indices in US dollars and in excess of risk-free rate. The sample period runs from January 1996 to December 2007 and includes 144 monthly observations.

\begin{tabular}{lcc|cc|c}
\hline & \multicolumn{2}{c|}{ Average } & \multicolumn{2}{c|}{ Beta } & Adj. $R^{2}$ \\
\cline { 2 - 6 } & $\begin{array}{l}\text { Excess } \\
\text { return }\end{array}$ & $\begin{array}{c}\text { Pricing } \\
\text { error } \alpha\end{array}$ & $\begin{array}{c}\text { World market } \\
\text { risk }\end{array}$ & $\begin{array}{c}\text { Emerging } \\
\text { markets risk }\end{array}$ & $\begin{array}{c}\text { Two-factor } \\
\text { model }\end{array}$ \\
\hline Russia & 0.019 & 0.004 & 0.202 & $1.762^{* \star *}$ & 0.452 \\
& & 0.012 & 0.450 & 0.309 & \\
Poland & 0.008 & -0.001 & $0.517^{* *}$ & $0.824^{* * *}$ & 0.451 \\
& & 0.006 & 0.215 & 0.137 & \\
Hungary & 0.017 & 0.009 & $0.695^{* * *}$ & $0.612^{* * *}$ & 0.358 \\
& & 0.007 & 0.212 & 0.178 & \\
Czech Republic & 0.015 & 0.009 & -0.083 & $0.760^{* * *}$ & 0.309 \\
& & 0.006 & 0.231 & 0.133 & \\
Bulgaria & -0.011 & -0.013 & -0.205 & 0.320 & -0.003 \\
& & 0.014 & 0.354 & 0.253 & \\
Slovenia & 0.016 & $0.014^{* *}$ & 0.014 & 0.191 & 0.014 \\
& & 0.006 & 0.184 & 0.135 & \\
Wald-test & & $10.734^{*}$ & $31.648^{* * *}$ & $92.542^{* * *}$ & Aver. Adj. $R^{2}$ \\
$(p$-value) & & $(0.097)$ & $(<0.001)$ & $(<0.001)$ & 0.264 \\
\hline
\end{tabular}

are reported in Table 7. Adding the currency risk factor to the pricing model seems to increase the overall explanatory power (the $R$-squareds increase by $17.3 \%$ on average from Table 6). Using a multivariate Wald-test statistic to test the joint significance of the risk factors, we find all four risk factors to be cross-sectionally significant. Ultimately, however, it seems that the emerging market risk and bilateral currency exchange rates are the most significant in explaining the returns. The cross-sectionally significant results for the two other risk factors are mostly driven by the highly significant returns for Hungary and Poland (as well as Russia in the case of multilateral currency risk).

\subsection{Time-Varying Beta Model}

Our final model drops the multilateral currency risk factor, as it was found to be cross-sectionally the least significant, and uses the other three risk factors from Table 7 . In addition, we allow the betas to be linearly time-varying with one conditioning information variable. In practice, the beta is modeled as follows: $\beta_{i t}=$ $=b_{0}+b_{1} Z_{i t-1}$, where $Z_{i t-1}$ is the first difference of the interest rate differential between the local short-term interest rate and the Eurodollar one-month rate. In the estimation, it has been demeaned so that the value for the constant, $b_{0}$, can be interpreted as the unconditional, average beta. The error term is now made orthogonal to the cross- 


\section{Table 7 Results for the Four-Factor APM with Constant Betas}

The results reported here are for the four-factor asset-pricing model. The risk factors used are: world market portfolio, aggregate emerging market portfolio, US currency index, and bilateral currency exchange rate. The world market portfolio is proxied by the $\mathrm{MSCl}$ world equity market index. The emerging market risk factor is measured using the aggregated emerging market portfolio. The US currency index is the official broad trade-weighted index. Standard errors are reported below in the alpha- and beta-parameter estimates. Significant parameters are marked with ${ }^{*},{ }^{* *}$, and ${ }^{* * *}(10 \%, 5 \%$, and $1 \%$ levels of significance, respectively). The estimation is conducted using the GMM with the Newey-West (1987) autocorrelation and heteroskedasticity consistent covariance matrix with only one iteration over the weighting matrix. The NW lags have been set to one. The model is fully identified. The Wald test is against the null hypothesis that the parameters in question are jointly zero (the $p$-value is provided in parenthesis). All returns are calculated from month-end total return indices in US dollars and in excess of the risk-free rate. The sample period runs from January 1996 to December 2007 and includes 144 monthly observations.

\begin{tabular}{|c|c|c|c|c|c|c|}
\hline & $\begin{array}{l}\text { Pricing } \\
\text { error } \\
a\end{array}$ & $\begin{array}{l}\text { World beta } \\
\qquad \beta_{w}\end{array}$ & $\begin{array}{c}\text { Emerging } \\
\text { market beta } \\
\beta_{e m}\end{array}$ & $\begin{array}{c}\text { Bilateral } \\
\text { fx-beta } \\
\beta_{f x, i}\end{array}$ & $\begin{array}{c}\text { Multilateral } \\
\text { fx-beta } \\
\beta_{f x}\end{array}$ & Adj. $R^{2}$ \\
\hline \multirow[t]{2}{*}{ Russia } & 0.011 & 0.313 & $1.690^{* * *}$ & $0.009^{* * *}$ & $-0.019^{* *}$ & 0.558 \\
\hline & 0.010 & 0.445 & 0.284 & 0.001 & 0.008 & \\
\hline \multirow[t]{2}{*}{ Poland } & -0.002 & $0.544^{\star * \star}$ & $0.714^{\star * *}$ & $0.014^{\star \star *}$ & $-0.019^{* * *}$ & 0.551 \\
\hline & 0.005 & 0.194 & 0.128 & 0.002 & 0.006 & \\
\hline \multirow[t]{2}{*}{ Hungary } & 0.003 & $0.912^{\star * *}$ & $0.677^{* * *}$ & $0.016^{\star * *}$ & $-0.034^{\star * *}$ & 0.467 \\
\hline & 0.006 & 0.212 & 0.174 & 0.003 & 0.008 & \\
\hline \multirow[t]{2}{*}{$\begin{array}{l}\text { Czech } \\
\text { Republic }\end{array}$} & 0.008 & 0.004 & $0.691^{* * *}$ & $0.010^{* * *}$ & -0.006 & 0.422 \\
\hline & 0.005 & 0.215 & 0.109 & 0.002 & 0.005 & \\
\hline \multirow[t]{2}{*}{ Bulgaria } & $0.012^{*}$ & -0.254 & $0.391^{* *}$ & $0.010^{* * *}$ & 0.003 & 0.594 \\
\hline & 0.007 & 0.275 & 0.163 & $<0.001$ & 0.006 & \\
\hline \multirow[t]{2}{*}{ Slovenia } & $0.016^{\star * *}$ & 0.019 & 0.217 & $0.007^{* *}$ & -0.004 & 0.044 \\
\hline & 0.006 & 0.186 & 0.152 & 0.003 & 0.008 & \\
\hline Wald-test & $20.775^{* * *}$ & $43.857^{* * *}$ & $112.507^{* * *}$ & $921.041^{* * *}$ & $23.714^{* * *}$ & Aver. Adj. $R^{2}$ \\
\hline ( $p$-value) & $(0.002)$ & $(<0.001)$ & $(<0.001)$ & $(<0.001)$ & $(<0.001)$ & 0.439 \\
\hline
\end{tabular}

-product of the risk factor and the conditioning variable. ${ }^{10}$ Thus, the parameter results are similar to the OLS results.

The results for the three-factor time-varying beta pricing model are reported in Table 8 . The explanatory power of the model with time-varying betas decreases slightly on average compared to the previous model. Somewhat surprisingly, the selected information variable is not found to be cross-sectionally significantly related to any of the risk factors at the standard significance level (the highest $p$-value is $6 . \%$ for the emerging market risk factor). Moreover, the unconditional world market risk is found to be significant for only two of the sample countries, showing evidence of segmentation. Thus, we re-estimate the model with just two risk factors. Again the beta is allowed to be time-varying. The results are reported in Table 9.

\footnotetext{
${ }^{10}$ The implied moment condition for asset $i$ can be written as follows for the one-factor world CAPM:

$$
E\left[r_{i t}-\alpha_{i}-\left(b_{0}+b_{1} Z_{i t-1}\right) r_{m t}\right]=0
$$
}

which is orthogonal to the constant and excess market returns (times one and $Z_{i t}$ ). 


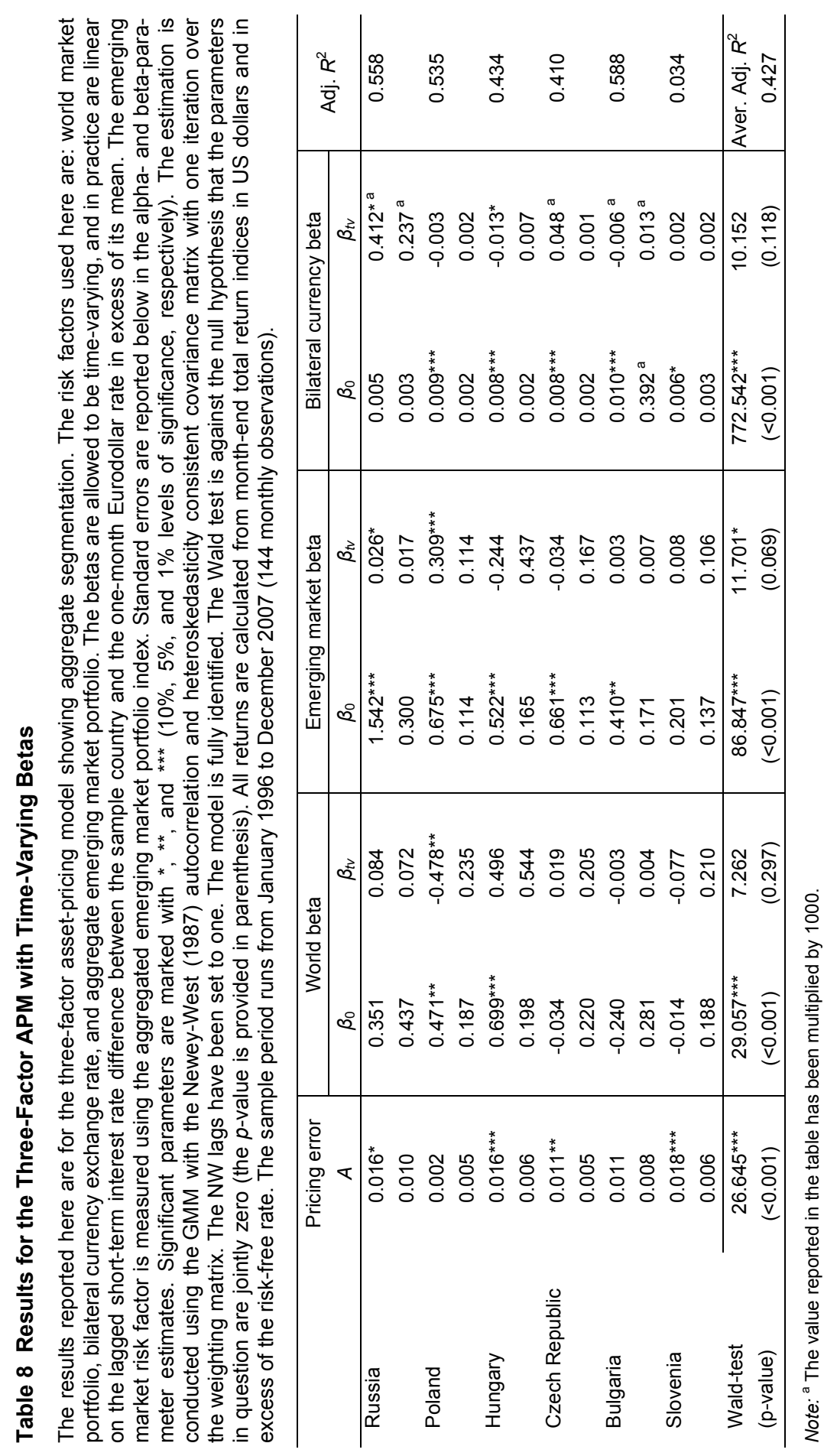




\section{Table 9 Results for the Two-Factor APM with Time-Varying Betas}

The results reported here are for the two-factor asset-pricing model showing aggregate segmentation. The risk factors used here are: bilateral currency exchange rate and aggregate emerging market portfolio. The betas are allowed to be time-varying. In practice, they are linear on the lagged short-term interest rate difference between the sample country and the one-month Eurodollar rate in excess of its mean. The emerging market risk factor is measured using the aggregated emerging market portfolio index. Standard errors are reported below in the alpha- and beta-parameter estimates. Significant parameters are marked with *, **, and ${ }^{* * *}(10 \%, 5 \%$, and $1 \%$ levels of significance, respectively). The estimation is conducted using the GMM with the Newey-West (1987) autocorrelation and heteroskedasticity consistent covariance matrix with one iteration over the weighting matrix. The NW lags have been set to one. The model is fully identified. The Wald test is against the null hypothesis that the parameters in question are jointly zero (the $p$-value is provided in parenthesis). All returns are calculated from month-end total return indices in US dollars and in excess of the risk-free rate. The sample period runs from January 1996 to December 2007 (144 monthly observations).

\begin{tabular}{ll|lc|cc|c}
\hline & Pricing & \multicolumn{2}{|c|}{ Emerging market beta } & \multicolumn{2}{|c|}{ Bilateral currency beta } & \\
& error $(\alpha)$ & $\beta_{0}$ & $\beta_{t v}$ & $\beta_{0}$ & $\beta_{t v}$ & Adj. $R^{2}$ \\
\hline Russia & 0.017 & $1.679^{* * *}$ & 0.015 & $0.006^{* *}$ & $0.314^{\mathrm{a}}$ & 0.555 \\
& 0.010 & 0.201 & 0.012 & 0.003 & $0.206^{\mathrm{a}}$ & \\
Poland & 0.005 & $0.833^{* * *}$ & 0.136 & $0.010^{* * *}$ & $-0.005^{\star *}$ & 0.513 \\
& 0.006 & 0.100 & 0.098 & 0.002 & 0.002 & \\
Hungary & $0.016^{* *}$ & $0.845^{* * *}$ & 0.126 & $0.008^{* * *}$ & $-0.012^{*}$ & 0.392 \\
& 0.007 & 0.160 & 0.265 & 0.002 & 0.007 & \\
Czech & $0.011^{* *}$ & $0.647^{* * *}$ & $-0.019^{* *}$ & $0.008^{* * *}$ & $-0.045^{\mathrm{a}}$ & 0.418 \\
Republic & 0.005 & 0.075 & 0.007 & 0.002 & $0.137^{\mathrm{a}}$ & \\
& -0.011 & 0.134 & $-0.061^{* * *}$ & $0.011^{* * *}$ & $-0.591^{\mathrm{a}}$ & 0.042 \\
Bulgaria & 0.013 & 0.185 & 0.014 & 0.004 & $0.245^{\mathrm{a}}$ & \\
& $0.014^{* *}$ & $0.134^{*}$ & $-0.069^{* * *}$ & $0.006^{* * *}$ & $0.001^{* * *}$ & 0.122 \\
Slovenia & 0.006 & 0.081 & 0.010 & 0.002 & $0.112^{\mathrm{a}}$ & \\
& $18.082^{* * *}$ & $200.205^{* * *}$ & $108.263^{* * *}$ & $63.880^{* * *}$ & $102.079^{* * *}$ & Aver. \\
Wald-test & $(0.006)$ & $(<0.001)$ & $(<0.001)$ & $(<0.001)$ & $(<0.001)$ & 0.340 \\
\hline
\end{tabular}

Note: ${ }^{\mathrm{a}}$ The value reported in the table has been multiplied by 1000 .

Almost all portfolios show significant sensitivity to emerging market and bilateral currency risk. Wald-test statistics support the pricing of these risk factors. Our conditioning instrument variable is also found to be cross-sectionally significant for both risk factors (although no clear pattern emerged from the estimation). The Wald test of the pricing errors (i.e., the multifactor efficiency of the risk factors) rejects the null hypothesis (the $p$-value is less than $0.1 \%$ ). Notably, the explanatory power of the model on average decreased by $7.4 \%$, suggesting further work is still needed to model the pricing of asset prices on emerging markets.

\section{Conclusions and Suggestions for Further Research}

In this paper, we studied the pricing of global and local sources of risk in six emerging Eastern European stock markets from a US investor's point of view. Using monthly data and an unconditional GMM estimation framework, we found that most markets show considerable segmentation. The local aggregate emerging market port- 
folio (emerging market risk factor), rather than the global market portfolio, was found to be the highly significant driver for the countries.

In addition, we showed currency risk to be a significant source of risk for US investors when investing in Eastern European countries. In the tests, we used measures for both multilateral and bilateral currency exchange rate risk. The results, which support bilateral currency exchange risk, suggest investors care most about country-specific currency risk. Finally, we estimated a model where the risk sensitivities (betas) were allowed to be time-varying with the country-specific interest rate difference vis-à-vis the world. The results reveal that the selected conditioning variable was cross-sectionally significant, especially when modeling time variation in emerging-market and bilateral currency risk.

The results did not give strong and consistent support for the asset-pricing model for partly segmented markets. However, the approach used here studied mostly the unconditional implications of the asset-pricing models. Moreover, the segmentation was assumed to be time-invariant. As a result, it would be interesting to study fully conditional models which allow for time-varying segmentation.

\section{REFERENCES}

Adler M, Dumas B (1983): International portfolio selection and corporation finance: a synthesis. Journal of Finance, 38:925-984.

Antell J, Vaihekoski M (2007): International Asset Pricing Models and Currency Risk: Evidence from Finland 1970-2004. Journal of Banking and Finance, 31(9):2571-2590.

Bekaert G, Harvey C (1995): Time-varying world market integration. Journal of Finance, 50:403-444 .

Brooks R, Del Negro M (2002): International stock returns and market integration: a regional perspective. IMF Working Paper 02/202.

Available at SSRN: http://papers.ssrn.com/sol3/papers.cfm?abstract_id=880844.

Campbell JY, Lo AW, MacKinlay AC (1997): The Econometrics of Financial Markets. USA, Princeton University Press.

De Jong F, De Roon F (2005): Time-varying market integration and expected returns in emerging markets. Journal of Financial Economics, 78:583-613.

De Santis G, Gérard B (1998): How big is the premium for currency risk? Journal of Financial Economics, 49:375-412.

De Santis G, Imrohoroglu S (1997): Stock returns and volatility in emerging financial markets. Journal of International Money Finance, 16:561-579.

Doukas J, Hall P, Lang L (1999): The pricing of currency risk in Japan. Journal of Banking and Finance, 23:1-20.

Errunza V, Losq E (1985): International Asset Pricing under Mild Segmentation: Theory and Test. Journal of Finance, 40:105-124.

Ferson W, Harvey C (1998): The fundamental determinants of national equity market returns: A perspective on country risk in asset pricing. Journal of Banking and Finance, 21:1625-1665.

Greene WH (2008): Econometric Analysis. 6th edition. USA, Prentice Hall.

Harvey C (1995a): Global risk exposure to a trade-weighted foreign currency index. Working Paper. Available at: http://faculty.fuqua.duke.edu/ charvey/Research/Working_Papers/ W10_Global_risk_ exposure.pdf.

Harvey C (1995b): Predictable risk and returns in emerging markets. Review of Financial Studies, $8: 773-816$. 
Hunter D (2006): The evolution of stock market integration in the post-liberalization period A look at Latin America. Journal of International Money and Finance, 25:795-826.

Jorion P (1990): The Exchange-Rate Exposure of U.S. Multinationals. Journal of Business, 63(3):331-345.

Jorion P (1991): The Pricing of Exchange Rate Risk in the Stock Market. Journal of Financial and Quantitative Analysis, 26(3):363-376.

King M, Segal D (2008): Market segmentation and equity valuation: Comparing Canada and the United States. Journal of International Financial Markets, Institutions and Money, 18(3):245-258 .

Korajczyk R (1995): A Measure of Stock Market Integration for Developed and Emerging Markets. World Bank Economic Review, 10(2):267-289.

MacKinlay A, Richardson M (1991): Using Generalized Method of Moments to Test Mean-Variance Efficiency. Journal of Finance, 46(2):511-527.

Saleem K, Vaihekoski M (2008): Pricing of global and local sources of risk in Russian stock market. Emerging Markets Review, 9(1):40-56.

Shackman J (2005): The equity premium and market integration: Evidence from international data. Journal of International Financial Markets, Institutions and Money, 16:155-179.

Vaihekoski M (2007): On the Calculation of the Risk Free Rate for Tests of Asset Pricing Models. Working paper. Available at SSRN: http://ssrn.com/abstract=958471. 